\title{
ANALYSIS REVENUE PROCESSING COFFEE IN KSU ARINAGATA PAYA TUMPI SUBDISTRICT KEBAYAKAN OF CENTRAL ACEH DISTRICT
}

\author{
${ }^{1}$ Eliyin, ${ }^{2}$ Fitri Ilma, ${ }^{3}$ Askura Nikmah, ${ }^{4}$ Zulida Susanti, ${ }^{5}$ Salmandi Putra \\ ${ }^{1}$ Study Program of Management Plantation Coffee, Faculty of Agriculture, University of Gajah Putih, Indonesia. \\ ${ }^{2}$ Study Program of Agribusiness, Faculty of Agriculture, University of Gajah Putih, Indonesia. \\ ${ }^{3,4,5}$ University of Gajah Putih, Indonesia
}

DOI: https://doi.org/10.51193/IJAER.2020.6606

\begin{abstract}
Given the importance of the development of the coffee processing business, this business requires a business analysis for the benefit of management in order to get significant benefits for the business. The amount of revenue obtained by KSU Arinagata in coffee processing is determined based on how much export coffee sales are sent to Medan and how much it costs to purchase original green coffee. The sales proceeds are expected to cover the purchase cost and be able to provide greater revenue benefits to KSU Arinagata. This is expected to strengthen the financial condition of KSU Arinagata. The purpose of this study was to determine the costs and revenues of coffee processing at KSU Arinagata Paya Tumpi, Kebayaan Sub-district, Central Aceh Regency. The hypothesis of this research is that it is suspected that the coffee processing process at KSU Arinagata Paya Tumpi, Kebayakan subdistrict, provides profitable income with the production costs incurred in the coffee processing process. The data analysis method used in this research is the analysis of revenue, income, $\mathrm{R} / \mathrm{C}$ ratio and BEP.

The research found that the coffee processing business at KSU Arinagata, Paya Tumpi District, Central Aceh Regency obtained an R / C ratio> 1, namely 1.11. The coffee processing business at KSU Arinagata, Paya Tumpi District, Central Aceh Regency has exceeded the break-even point (BEP). BEP for revenue of IDR 175,915,453.27; BEP production of 2,545.50 kg; and the BEP price of IDR $64,677.02 / \mathrm{kg}$. The average income of the coffee processing business at KSU Arinagata in 2017 was Rp. $365,849,916.49$. The largest component of the total variable cost is the cost of raw materials, which is IDR $22,476,203,432.20$ or $96.30 \%$.
\end{abstract}


Volume: 06, Issue: 06 "November-December 2020"

The conclusion of this study is that the coffee processing process at KSU Arinagata Paya Tumpi, Kebayaan subdistrict, provides profitable income with the production costs incurred in the coffee processing and is feasible to be cultivated.

Keywords: Cost, Income, Coffee Processing

\section{INTRODUCTION}

Apart from being a foreign exchange earner, coffee is also a commodity that has an important role as a provider of employment and as a source of income for farmers or other economic factors related to coffee. The people of Central Aceh in particular, coffee is a superior plantation crop for farmers, most of the farmers in Central Aceh depend on coffee as the main source of income to sustain their life.

Over time, business people do not want to be left behind in taking the right steps to start by seeing good prospects in running a business in the coffee processing sector. However, in starting a business it is necessary to consider all basic aspects, so that in running the business it can achieve financial benefits.

Currently, many businesses are engaged in agriculture, especially coffee processing. One of the companies engaged in the coffee processing business is the Arinagata Multipurpose Cooperative (KSU) which is located in Paya Tumpi, Kebayaan District, Central Aceh Regency.

KSU Arinagata is a company engaged in buying and selling coffee. KSU Arinagata usually buys coffee in the form of green coffee beans random and specialty. Especially for green coffee asalan is coffee with a water content of $13 \%$. The process steps that the original green coffee must go through until it is ready to be exported, from coffee with a moisture content of $13 \%$, then it is put into the Sutton machine to separate good quality coffee and bad quality coffee, then from the Sutton machine, the good coffee is sorted for selected coffee ready for export. KSU Arinagata, in the process of exporting its coffee, contracts annually with buyers.

The coffee beans purchased by KSU Arinagata are coffee beans from assisted farmers and conventional (general) coffee beans. Assisted farmers are farmers who have officially registered coffee special certificates. Meanwhile, conventional farmers are farmers who do not have certain certification.

The peak period of the peak coffee harvest in one year occurs twice, namely the first period between March to June and the second period between September to December. Meanwhile, KSU Arinagata purchased random green coffee during the first harvest period, namely March to 
Volume: 06, Issue: 06 "November-December 2020"

June and during the second harvest period, namely September. During the harvest period, the number of purchases made by KSU Arinagata from farmers through collectors will increase.

The following is data on the amount and cost of purchasing random green coffee at KSU Arinagata.

Table 1: Amount and Cost of Purchasing Green Coffee at KSU Arinagata

\begin{tabular}{|c|c|c|c|}
\hline No & Month & Amount(Kg) & Cost (Rp) \\
\hline 1 & January 2019 & $20.500,0$ & $1.190 .332 .500,0$ \\
\hline 2 & March 2019 & $61.954,9$ & $3.597 .411 .268,5$ \\
\hline 3 & April 2019 & $63.437,0$ & $3.556 .722 .279,0$ \\
\hline 4 & May 2019 & $83.852,0$ & $4.712 .230 .844,0$ \\
\hline 5 & June 2019 & $19.454,1$ & $1.108 .669 .704,9$ \\
\hline 6 & September 2019 & $62.463,4$ & $3.498 .699 .960,8$ \\
\hline \multirow[t]{3}{*}{7} & December 2019 & $82.875,0$ & $4.812 .136 .875,0$ \\
\hline & Amount & $394.536,5$ & $22.476 .203 .432,2$ \\
\hline & Average & $56.362,4$ & $3.210 .886 .204,6$ \\
\hline
\end{tabular}

Source: Arinagata KSU data processed by year 2019

The amount of revenue that KSU Arinagata earns in coffee processing is determined based on how much sales of ready-to-export coffee are and how much it costs to purchase the original green coffee planted. The sales proceeds are expected to cover the purchase cost and be able to provide greater revenue benefits to KSU Arinagata. This is expected to strengthen the financial condition of KSU Arinagata.

Based on this background, the researchers are interested in conducting research on the analysis of costs and income of coffee processing at KSU Arinagata Paya Tumpi, Keb Kebayaan Subdistrict, Central Aceh Regency.

\section{LITERATUREREVIEW}

\section{Ministry of Cooperatives}

According to Rudianto (2010: 3), cooperatives are "associations of people who voluntarily unite themselves to strive to improve their economic welfare through the formation of a business entity that is managed democratically."

According to Law Number 25 of 1992 concerning Cooperatives, cooperatives are "business entities whose members are individual or cooperative legal entities by basing their activities on 
International Journal of Agriculture and Environmental Research

ISSN: 2455-6939

Volume: 06, Issue: 06 "November-December 2020"

the principles of cooperatives as well as a people's economic movement based on the principle of kinship."

According to the Regulation of the State Minister for Cooperatives and UKM RI Number 04 of 2012 concerning General Guidelines for Cooperative Accounting, that "Cooperatives are business entities whose members are individual or cooperative legal entities based on their activities based on cooperative principles, as well as a people's economic movement based on the principle of kinship."

Based on the above understanding, it can be concluded that a cooperative is a business whose members are individuals or cooperative legal entities that carry out their business activities based on the principle of kinship and have the aim of advancing the welfare of members and society and building a national economic order.

\section{Production cost}

According to Sutriono (2006: 48) that production costs are the value of a convention as a result of using production costs, usually in another production plan, production costs occupy a very important position because decision making on this matter needs to use considerations so that production costs are met, so that the production process is going well. Production costs are all expenses incurred by producers to obtain production factors and other supporting materials that will be used for the well-planned production of certain products.

Soekartawi (2002: 124) states that production costs are usually classified into two, namely fixed costs: and variable costs. Fixed costs are generally defined as costs that are relatively fixed in number, and are continuously incurred even if the production obtained is a lot or a little. So the amount of fixed costs does not depend on the size of the production obtained. On the other hand, fixed costs or variable costs are usually defined as costs that are influenced by the production obtained.

Based on the above understanding, it can be concluded that the production cost is a business whose members are individuals or cooperative legal entities that carry out their business activities based on the principle of kinship and have the aim of advancing the welfare of members and society and building a national economic order.

In processing coffee there is a production cost. The production costs are costs incurred in managing the farm according to a certain time; these costs are divided into fixed costs and variable costs. The components of production costs are as follows. 
International Journal of Agriculture and Environmental Research

ISSN: 2455-6939

Volume: 06, Issue: 06 "November-December 2020"

\section{Fixed Costs}

Fixed costs are costs that are not used up in one production process or capital that are not related to the amount of production produced and must be paid even if the plant does not produce, which are included in fixed costs, namely, depreciation costs, land rental costs and taxes. Sutriono (2006: 58)

\section{Variable Costs}

Variable or variable costs are costs incurred in a one-time production process, included in the costs are the costs of purchasing seeds, fertilizers, land cultivation and labor wages. Sutriono (2006: 60)

The production costs required in coffee farming are in the form of investment costs and operational costs. Investment costs are the costs incurred by farmers at the beginning of planting coffee until the coffee plants are immature, consisting of costs for obtaining land and land clearing, costs for obtaining equipment, coffee plant seeds, shade, and blenders, as well as costs for maintaining coffee plants before producing them such as fertilizers, medicine, and labor.

According to Prasmatiwi, et al, (2010: 83), in year 1 farmers incur high land and equipment costs, and in year 2, coffee farming costs are the smallest and then increase again in years 3 and 4. After the coffee plants produce, generally the costs incurred by farmers for managing coffee farming are the same every year. The difference in costs will occur in harvesting and milling activities, where the need for labor in these activities depends on the production of coffee produced.

The costs for managing the coffee plants consist of labor costs and input costs. Labor costs are needed for fertilization, pruning, harvesting, and processing, while the costs for production facilities, such as the cost of buying fertilizers, medicines, and sacks.

\section{Depenisi random coffee}

Original coffee is coffee that has not undergone further processing, namely grading and which still requires processing coffee beans into quality coffee. It is called random coffee because it is still mixed with skin, logs and others (unlike grade coffee that has been processed and separated) and still has a high enough moisture content. Asalan coffee still has relatively high water content (>16\%) and is still mixed with large amounts of non-coffee ingredients. (Suharyanto, 2012: 93).

In the stage of drying random coffee beans, some farmers use three different methods, some use drying beds to dry naturally using the sun, others dry them using a dryer, and the last way there 
is also a combination of the two begins with natural drying and drying, with the dryer. For the best choice, this is an optional coffee farmer, natural drying requires less investment with a lot of management, using a dryer definitely requires a large investment. (Najiyati, et al, 2004: 142).

Price is a very important part of marketing a product. Price is also one of the determinants of the success of a farm because price determines how much profit will be obtained from selling the product. (Suratiyah, 2008: 131).

Price is the amount of money needed to get something or a number of goods or services that are attached (ingherent) to the goods. (Firdaus, 2007: 89).

Price is an important element in determining a company's revenue because revenue is the product of the price and the quantity sold. (Hernanto, 2006: 152).

Price is the amount of money that consumers have to pay to get the product. Price is the amount of money (plus some products if possible) needed to get the combination of goods and services. (Assauri, 2008: 59).

Soekartawi (2002: 73) argues that the production produced is acceptance in the form of physical results measured in units of $\mathrm{Kg}$, the size of the production value obtained is very much determined by the level of price and volume of production. The statement can be stated in the following formula.

$\mathrm{TR}=\mathrm{Y} \times \mathrm{PY}$

Where:

TR: Total revenue or production value

Y: Production obtained in coffee processing

PY: The price earned in processing coffee

\section{Income}

The income earned is the net profit in farming, according to the farmer's goal in doing business is to get the profit that is achieved. The amount of income received by a farmer varies, depending on the amount of production produced by the farmer, the quality of the coffee beans produced (the size of the coffee beans) because it relates to the selling price. the bigger the coffee beans are produced, the more expensive the selling price will be. (Sutrisno, 1983: 126). 
Suratiyah (2006: 152) states that gross income is the total income obtained from a farm during one period calculated from sales or re-assessment.

Then according to Soekartawi (2002: 81) that gross income is the income obtained from farming during a period of business which is calculated from the proceeds of sale and exchange. net income is a measure of profit that can be used to compare several farming alternatives.

Income can be said that the results are satisfactory if the value of production is higher than the cost of production, on the other hand, if the cost of production is higher than the value of the output, it is said that the farming is unsatisfactory or loss. Income is an inflow or increase in value received during a certain period, which comes from the delivery of production of goods. Through the implementation of other activities which are the company's main ongoing activities.

Soekartawi, (2002: 88) says that the income or profit of a business can be calculated using the following mathematical equation:

$\pi=\mathrm{TR}-\mathrm{TC}$

$\mathrm{TR}=\mathrm{P} \times \mathrm{Q}$

$\mathrm{TC}=\mathrm{TFC}+\mathrm{TVC}$

Where:

$\pi$ : Income (profit)

TR: Total Revenue (Total Revenue)

TC: Total Cost

: Price

: Quantity (Unit)

TFC: Total Fixed Cost

TVC: Total Variable Cost

Analysis of farm income is important, meaning that it is related to the goals to be achieved by each farm, with various considerations and motivations. Basically, income analysis requires two 
main information, namely the state of income and the state of expenditure (production costs) for a certain period of time. (Hernanto, 2006: 162).

\section{Analysis of R / C Ratio and Business Profits}

According to Rianse (2005: 153), R / C Ratio stands for Return Cost Ratio, or known as the ratio / ratio between revenues and costs. Mathematically, the $\mathrm{R} / \mathrm{C}$ ratio can be written as follows:

$\mathrm{R} / \mathrm{C}$ Ratio $=\mathrm{TR} / \mathrm{TC}$

Where:

$$
\begin{aligned}
& \mathrm{R} / \mathrm{C} \text { Ratio }=\text { the ratio of production cost of coffee processing } \\
& \mathrm{TR}=\text { Total revenue from coffee processing } \\
& \mathrm{TC}=\text { Total cost of processing coffee }
\end{aligned}
$$

\section{Decision rule:}

If the R / C Ratio> 1, then it is said to be profitable, it is worth working on

If R / C Ratio = 1, then break-even (= BEP), still worth working on

If the $\mathrm{R} / \mathrm{C}$ Ratio <1, then it is said to be a loss, not worth working on

\section{Break Even Point (BEP)}

According to Suratiyah (2009, 90-95), states that the Break Even Point (BEP) or break-even point is a condition that describes a company that does not earn a profit and also does not suffer losses. The company will reach a state of BEP when total revenues are equal to total costs. BEP analysis or so-called breakeven analysis is an analytical technique that companies can use when they are neither profitable nor losing.

\section{METHODS OF RESEARCH}

\section{Location and Time of Research}

The research location is at KSU Arinagata, Paya Tumpi Village, Keb Kebayaan Sub-district, Central Aceh Regency. The determination of the research location was carried out purposively (purposive sampling), with the consideration that KSU Arinagata Paya Tumpi is one of the 
multi-business cooperatives engaged in the coffee processing business. This research was conducted from January 1, 2019 to December 5, 2019.

\section{The scope of research}

The scope of this research is limited to the analysis of costs and revenues of coffee processing at KSU Arinagata Paya Tumpi, Kebayaan Sub-district, Central Aceh Regency.

\section{Data analysis method}

R / C Ratio (Return Cost Ratio)

$\mathrm{R} / \mathrm{C}$ Ratio $=\mathrm{TR} / \mathrm{TC}$

Where:

$\mathrm{R} / \mathrm{C}$ Ratio $=$ the ratio of production cost of coffee processing

$\mathrm{TR}=$ Total revenue from coffee processing

$\mathrm{TC}=$ Total cost of processing coffee

\section{Decision rule:}

If the R / C Ratio> 1, then it is said to be profitable, it is worth working on

If R / C Ratio = 1, then break-even (= BEP), still worth working on

If the $\mathrm{R} / \mathrm{C}$ Ratio $<1$, then it is said to be a loss, not worth working on

\section{Reception}

Total revenue $=\mathrm{TR}=\mathrm{P} \times \mathrm{Q}$

$\mathrm{TR}=$ Total Revenue $=$ total revenue $(\mathrm{IDR})$ from coffee processing production

$$
\begin{aligned}
& \mathrm{P}=\text { Price }=\text { price of green bean coffee per } \mathrm{kg} \\
& \mathrm{Q}=\text { Quantity }=\text { the number of coffee products produced }
\end{aligned}
$$

\section{Income}


$\pi=\mathrm{TR}-\mathrm{TC}$

$\mathrm{TR}=\mathrm{P} \times \mathrm{Q}$

$\mathrm{TC}=\mathrm{TFC}+\mathrm{TVC}$

Where :

is income

TR is the total revenue from the sale of the number of products produced (the number of products multiplied by the prevailing price).

TC is the total cost incurred in the production process

The decision making criteria are as follows:

TR> TC, green coffee processing business as long as it is profitable.

TR $<$ TC, green coffee processing business as long as it is not profitable.

$\mathrm{TR}=\mathrm{TC}$, green coffee processing business as long as it is neither profitable nor loss.

\section{Break Even Point (BEP)}

$\mathrm{BEP}$ reception $=\mathrm{FC} /(1-\mathrm{VC} / \mathrm{S})$

Information:

FC $=$ Fixed cost of coffee processing production

$\mathrm{VC}=$ Variable Cost of coffee processing production

$\mathrm{S}=$ Value of Production / Receipt of coffee processing production

Decision criteria:

If Acceptance> BEP Acceptance, it is said to be profitable

If Receipt = BEP Receipt, it is said to be breaking even. If Receipt <BEP Receipt, it is said to be loss 
Production $\mathrm{BEP}=\mathrm{FC} /(\mathrm{P}-\mathrm{AVC})$

Information:

$\mathrm{FC}=$ Fixed cost of coffee processing production

$\mathrm{AVC}=$ Average Variable Cost of coffee

$\mathrm{P}=$ Price

Decision criteria:

If production> BEP production, it is said to be profitable

If production $=\mathrm{BEP}$ production, then it is said to be breaking even

If production $<\mathrm{BEP}$ production, it is said to be a loss

c. $\quad$ BEP Price $=\frac{T C}{\mathrm{Y}}$

Information:

TC $=$ Total Cost coffee processing

$Y \quad=$ Production coffee processing

Decision criteria:

If the price> BEP price, it is said to be profitable

If price $=\mathrm{BEP}$ price, it is said to be breaking even

If the price $<\mathrm{BEP}$ price, then it is said to be a loss

\section{RESULTS AND DISCUSSION}

Revenue from Coffee Processing Business at KSU Arinagata

The business income referred to in the research is the total amount of production multiplied by the prevailing price minus the production costs incurred by KSU Arinagata during the production process, whether paid in cash or not paid in cash during the production process. The size of the 
income received by KSU Arinagata is very much influenced by the high and low production level. Besides, it is also determined by the price level prevailing in the market.

Table 3: Income from Coffee Processing Business at KSU Arinagata Production Year 2019

\begin{tabular}{lll}
\hline No & Description & $\begin{array}{c}\text { Amount cost } \\
(\mathrm{Rp})\end{array}$ \\
\hline 1 & Total Revenue) & $25.919 .377 .007,60$ \\
2 & Total Cost & $23.358 .427 .592,20$ \\
\hline & Income & $2.560 .949 .415,40$ \\
\hline
\end{tabular}

Source: Primary data processed 2019

Based it shows that the total production value (total revenue) or total revenue (TR) at KSU Arinagata is Rp. 25,919,377,007.60 with a production cost or total cost (TC) of IDR 23,358,427,592.20, you will get an income of IDR 2,560,949,415.40.

\section{Analysis of R / C (Return Cost) Ratio}

R / C Ratio stands for Return Cost Ratio, or known as the ratio / ratio between revenues and costs. This $\mathrm{R} / \mathrm{C}$ ratio shows an illustration of how many times the profit that will be obtained from the costs incurred. Calculations to determine the profits of a business based on the amount of capital issued can be calculated using the equation.

$$
R / C \text { Ratio }=\frac{T R}{T C}
$$

Based on the research results, it was found that:

$$
\begin{aligned}
& T R=\text { total reception }=\mathrm{Rp} 25.919 .377 .007,60 \\
& T C=\text { total cost }=\mathrm{Rp} 23.358 .427 .592,20
\end{aligned}
$$

then $R / C$ Ratio $=\frac{\mathrm{TR}}{\mathrm{TC}}=\frac{\operatorname{Rp} 25.919 .377 .007,60}{\operatorname{Rp} 23.358 .427 .592,20}=1,11$

The results of the research obtained from the field indicate that the $\mathrm{R} / \mathrm{C}$ ratio $=$ IDR $25,919,377,007.60 /$ IDR 23,358,427,592.20 = 1.11. The value of $\mathrm{R} / \mathrm{C}$ ratio $>1$ is 1.11 . So it is said that this business is profitable and worth working on. because the total revenue (production value) is greater than the cost of production. More details can be seen in appendix 9 . 
International Journal of Agriculture and Environmental Research

ISSN: 2455-6939

Volume: 06, Issue: 06 "November-December 2020"

With the R / C ratio of the Arinagata KSU coffee processing business of 1.11 , the KSU Arinagata coffee processing business is able to provide benefits and each additional capital of Rp. 1.00 will be obtained in the amount of Rp. 1.11 .

\section{Break Even Point Analysis (BEP)}

Analysis of the break even point (BEP) is to determine the break-even point or a condition where the results of the business do not get profit and do not suffer losses, in other words this calculation can reach the principal return.

Based on the calculation results, it was found that the total revenue was IDR 25,919,377,007.60 and the production cost was IDR 23,358,427,592.20. Meanwhile, the BEP for revenue was IDR 175,915,453.27. This means that the coffee processing business has exceeded the break even point, because revenue> BEP acceptance or Rp. 25,919,377,007.60> Rp. 175,915,453.27. For more details, see attachment 10 (b.1).

The production in the field is $361,155.00 \mathrm{~kg}$, which means it is above the BEP Production of $2,545.50 \mathrm{~kg}$. So the coffee processing business has exceeded the break even point, because production> BEP production or $361,155.00 \mathrm{~kg}>2,545.50 \mathrm{~kg}$.

The average selling price that applies in the field is IDR $71,503.43 / \mathrm{kg}$, which means that it is above the BEP price of IDR 64,677.02 / kg. So that the coffee processing business has exceeded the break even point because the price> BEP price or IDR 71,503.43 / kg> IDR 64,677.02 / kg. For more details, see attachment 10 (b.3).

Based on the data analysis, the results show that the coffee processing business at KSU Arinagata, with total revenue of IDR 25,919,377,007.60, has exceeded the BEP's break-even point of IDR $175,915,453.27$. Production of $361,155.00 \mathrm{~kg}$ has exceeded the break-even point for BEP production of $2,545.50 \mathrm{~kg}$.

Meanwhile, the average selling price of IDR 71,503.43 / $\mathrm{kg}$ has exceeded the BEP break-even point of IDR $64,677.02 / \mathrm{kg}$. So it can be said that the coffee processing business at KSU Arinagata is profitable and feasible to run.

Based on the above analysis, the research hypothesis is answered that the coffee processing process at KSU Arinagata Paya Tumpi, Keb Kebayaan District, provides profitable income with production costs incurred in the coffee processing, with the following research results.

The coffee processing business at KSU Arinagata earns an operating income of Rp. 2,560,949,415.40. The coffee processing business at KSU Arinagata, Paya Tumpi District, 
Volume: 06, Issue: 06 "November-December 2020"

Central Aceh Regency obtained an R / C ratio of > 1, namely 1.11, derived from revenue divided by costs or IDR 25,919,377,007.60 / IDR 23,358,427,592, $20=1.11$. This shows that each additional cost of capital is Rp. 1.00 will get an income of Rp. 1,11, so it can be said that this business is profitable because the total revenue (production value) is greater than the production cost.

The coffee processing business at KSU Arinagata, Paya Tumpi District, Central Aceh Regency has exceeded the break-even point (BEP). The revenue of IDR 25,919,377,007.60 is already above the BEP of IDR 175,915,453.27. The production of $361,155.00 \mathrm{~kg}$ means that the production BEP is above $2,545.50 \mathrm{~kg}$. The average selling price that applies in the field is IDR $71,503.43 / \mathrm{kg}$, which means that it is already above the BEP price of IDR 64,677.02 / kg.

The following is a graph of the Break Even Point of the coffee processing business at KSU Arinagata.

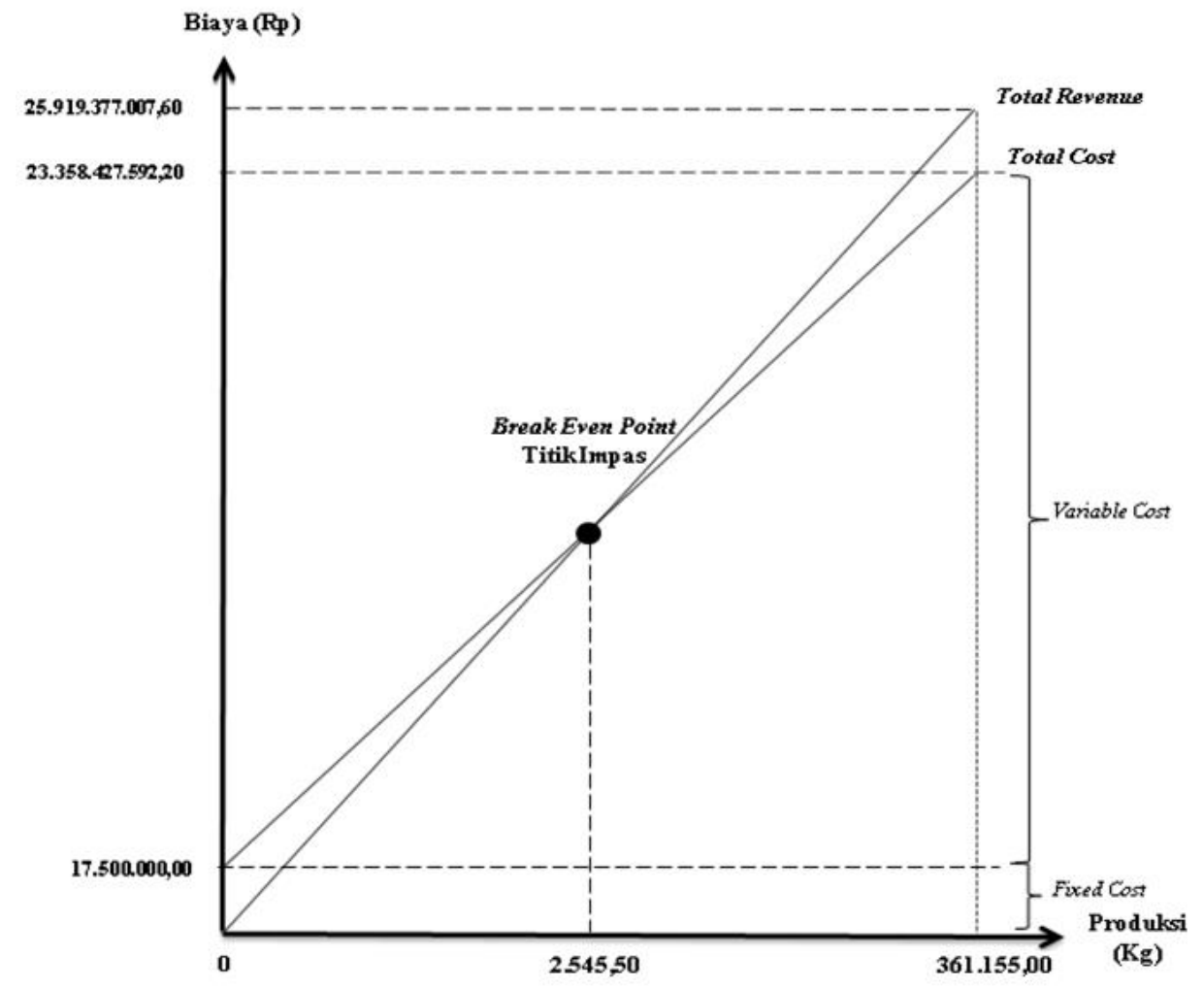

Figure 3: Break Even Point Curve in Coffee Processing Business at KSU Arinagata 
International Journal of Agriculture and Environmental Research

ISSN: 2455-6939

Volume: 06, Issue: 06 "November-December 2020"

Based on the break even point (BEP) curve image above, it can be determined, when the total revenue line (TR) shows that the costs earned in the coffee processing business at KSU Arinagata is Rp. 25,919,377,007.60. This means that the total revenue will experience BEP.

When the total cost line (TC) is drawn horizontally from that point to the $\mathrm{Y}$ axis, you will see the amount of BEP in rupiah. So the coffee processing business at KSU Arinagata is IDR 23,358,427,592.20.

When the fixed cost line (FC) from that point is drawn horizontally to the side, it will show the amount of fixed costs in the coffee processing business at KSU Arinagata of Rp. 17,500,000.00. So that the amount of variable costs in the coffee processing business at KSU Arinagata is IDR 23,340,927,592.20.

\section{CONCLUSION AND RECOMMENDATIONS}

The conclusions of this study are as follows.

1. The coffee processing business at KSU Arinagata, Paya Tumpi District, Central Aceh Regency obtained an R / C ratio> 1, namely 1.11 .

2. The coffee processing business at KSU Arinagata, Paya Tumpi District, Central Aceh Regency has exceeded the break-even point (BEP). BEP for revenue of IDR $175,915,453.27$; BEP production of 2,545.50 kg; and the BEP price of IDR 64,677.02 / $\mathrm{kg}$.

3. The average income of the coffee processing business at KSU Arinagata in 2019 is Rp. $365.849 .916,49$.

4. The largest component of total variable costs is the cost of raw materials which is equal to $\operatorname{Rp} 22.476 .203 .432,20$ atau $96,30 \%$.

\section{Recommendations:}

1. It is hoped that the Ariganata KSU will further reduce the cost of electricity and water in order to reduce variable costs.

2. It is hoped that the Arinagata KSU can increase revenue by further improving the quality of ready-to-export coffee so that the selling price increases.

\section{REFERENCES}

1. Assauri, 2008, Manajemen Produksi, LPFPUL, Jakarta

2. $\quad$ Firdaus, 2007, Analisis Usahatani, UI-Press, Jakarta

3. Hernanto, F, 2006, Ilmu Usaha Tani, Penerbit Swadaya, Jakarta 
International Journal of Agriculture and Environmental Research

ISSN: 2455-6939

Volume: 06, Issue: 06 "November-December 2020"

4. Najiyati, S, 2004, Budidaya Tanaman Kopi dan Penanganan Pasca Panen, Penebar Swadaya, Jakarta

5. Rudianto, 2010, Akuntansi Koperasi edisi kedua, Erlangga, Jakarta

6. Rianse, U, 2005, Metodologi Penelitian Sosial Ekonomi, Alfabeta, Bandung

7. Undang-Undang Nomor 25 Tahun 1992 Tentang Perkoperasian, Jakarta

8. Peraturan Menteri Negara Koperasi dan Usaha Kecil dan Menengah, Republik Indonesia, Nomor 04/ Tahun 2012. tentang Pedoman Umum Akuntansi Koperasi, Jakarta

9. Prasmatiwi, I, Suryantini, Jamhari, 2010, Analisis Keberlanjutan Usahatani Kopi di Kawasan Hutan Kabupaten Lampung Barat dengan Pendekatan Nilai Ekonomi Lingkungan, Jurnal

10. Soetriono, dkk. 2006, Pengantar Ilmu Pertanian, Banyumedia Publishing, Malang

11. Soekartawi. 2002, Analisis Usahatani, UI-Press, Jakarta

12. Suharyanto, 2012, Budidaya Kopi. http://budidaya-tanaman-kopi.htm, diakses pada tanggal 20 Desember 2017

13. Suratiyah, K, 2009, Ilmu Usahatani, Penebar Swadaya, Jakarta 